Original Article

\title{
PRESENCE AND LEVELS OF CONCENTRATION OF POLYCYCLIC AROMATIC HYDROCARBONS (PAHS) IN SMOKED FISH, HIDES AND SKIN OF SLAUGHTER CATTLE AND GOATS IN AWKA URBAN, NIGERIA
}

\author{
IKECHUKWU OFOMATA ${ }^{1}$, LYNDA ONYINYE OBODOECHI ${ }^{1}$, REGINALD IKECHUKWU OBIDIKE ${ }^{2}$, JOHN ANAELOM \\ NWANTA $^{1}$
}

${ }^{1}$ Department of Veterinary Public Health and Preventive Medicine, University of Nigeria, Nsukka, ${ }^{2}$ Department of Veterinary Physiology and Pharmacology, University of Nigeria, Nsukka

Email: onyinye.obodoechi@unn.edu.ng

Received: 15 Nov 2018, Revised and Accepted: 20 Feb 2019

\begin{abstract}
Objective: This study evaluated the presence and concentration of PAHs in singed and unsinged hides and skin of slaughter cattle and goats and smoked and non-smoked fish in Awka urban area of Anambra State, Nigeria.

Methods: Sixty samples of singed and unsinged hides and skin for were collected from Kwata slaughterhouse in Awka town where fish tissues were also collected from fish smoking spots in Awka urban. The samples were examined for the presence PAHs such as: benzo[a]pyrene; benzo[a]anthracene; benzo[k]flouranthene and indeno[1-2-3cd]pyrene using gas chromatography equipped with flame ionization detector.

Results: The result showed that the mean concentrations $(\mu \mathrm{g} / \mathrm{kg})$ of benzo[a]pyrene and indeno [1-2-3cd]pyrene in unsinged cattle hides were $7.89 \pm 7.77$ and $2.25 \pm 0.97$ respectively. The mean concentrations upon singeing were of $15.81 \pm 14.93$ and $3.55 \pm 2.89$. The mean concentrations $(\mu \mathrm{g} / \mathrm{kg})$ of benzo[a]pyrene; benzo[k]flouranthene and indeno[1-2-3cd]pyrene in unsigned goat skins were $6.52 \pm 10.77 ; 6.58 \pm 5.93$ and $3.48 \pm 0.00$ respectively. When the goatskin was singed, the mean concentrations were $17.50 \pm 26.03 ; 10.84 \pm 11.19$ and $8.79 \pm 11.77$. The mean concentrations $(\mu \mathrm{g} / \mathrm{kg})$ of benzo[a]pyrene; benzo[k]flouranthene and indeno[1-2-3cd]pyrene in non-smoked fish were 8.65 $\pm 9.67 ; 2.11 \pm 2.10$ and $54.76 \pm 60.35$ respectively. When the fish were smoked, the mean concentrations of $26.42 \pm 40.21 ; 6.64 \pm 11.11$ and $599.36 \pm 1395.61$ were recorded respectively. In all species of animals sampled, no trace of benzo[a]anthracene was detected.
\end{abstract}

Conclusion: The mean concentrations of all carcinogenic PAHs detected in this work were below the maximum permissible level set by World Health Organization (WHO) and European Commission $(30 \mu \mathrm{g} / \mathrm{kg}$ ) with the exception of indeno[1-2-3cd]pyrene in smoked and non-smoked fish, which was far above the permissible level.

Keywords: Polycyclic Aromatic Hydrocarbons, Smoked fish, Cattle hide, Goat skin, Awka Urban

(c) 2019 The Authors. Published by Innovare Academic Sciences Pvt Ltd. This is an open access article under the CC BY license (http://creativecommons.org/licenses/by/4.0/) DOI: http://dx.doi.org/10.22159/ijcpr.2019v11i2.33014

\section{INTRODUCTION}

Polycyclic aromatic hydrocarbons (PAHs) are among ubiquitous chemicals that abound in the environment. They constitute a large class of organic compounds, containing 2 or more fused aromatic rings made up of carbon and hydrogen atoms [1].

When food items, particularly meat, meat products and fish are subjected to thermal treatment (singeing, smoking, roasting, grilling or barbecuing), PAHs are formed as a result of incomplete combustion or thermal decomposition of organic materials [2]. Pyrolysis of fats in the meat or fish generates PAHs that become deposited on the meat and fish. The production of PAHs during roasting over charcoal is a function of the fat content of the meat and fish, temperature, duration of treatment, distance from the source of heating, oxygen accessibility and type of combustion used [3]. Several analysis of charcoal roasted/grilled common food items have shown the presence of PAHs, such as benzo[a]anthracene, benzo[a]pyrene, indeno[1,2,3-c,d] pyrene $[4,5]$. Very high contamination levels are expected when food is smoked over an open flame, while charcoal grilling usually yields small amounts of PAHs [6].

Fish as well contain very low PAHs concentrations, even when they come from heavily contaminated areas because of their ability to rapidly metabolize PAHs [7]. The amount of PAHs reported in fish from the same contaminated area revealed a correlation with their lipid content, indicating the ability to bio-accumulate PAHs in their fatty tissue $[3,4]$. There is considerable evidence to show that PAHs are enzymatically converted to reactive metabolites that bind covalently to cellular macro-molecules [8]. The covalent binding to reactive metabolites to deoxyribonucleic acid (DNA) is considered to be an important step in tumor initiation by the carcinoges [9] Therefore, PAHs are well known for their mutagenic and carcinogenic effect and subsequently bio-accumulate in animal and human tissues. Polycyclic aromatic hydrocarbons can enter into human food chain and could result in health problem [10].

On the other hand, it must be emphasized that aquaculture industries are also exposed to many chemical, biological, and other pollutants including PAHs which also contribute to pollution in aquaculture facilities and thus need to be further investigated. Singeing of hides and skin of cattle and goat is a common practice for processing of meat products for human consumption, whereas smoking of fish is an age long technique that is largely favoured in African traditional society [11].

During the singeing of hides and skin in slaughterhouses in Nigeria, butchers use old tyres, plastics, polythene, spent engine oil, kerosene to fuel woods. The singed hides and skin (popularly known as "ponmo" or "Ganda") are used in making soup in hotels, restaurants and homes in Anambra State and other parts of Nigeria. Similarly, smoked fish is commonly sold and consumed as ready-to-eat snacks by large population of Anambra State yet the public health significance of this practice has not been studied. Frozen and fresh fish samples are scaled and eviscerated, washed in water and steeped into palm oil mixed with dried pepper and salt. These preparations are then placed on an open charcoal fire. The PAHs on fish and animal products have been shown to come from both natural and anthropogenic sources mainly from incomplete combustion of organic materials, fossil fuel and petroleum products [12]. Food processing involving thermal treatment at high temperature (singeing, smoking, toasting, roasting or grilling) could be responsible for the presence of Polycyclic 
Aromatic Hydrocarbons (PAHs) in animal products (Hides and Skin), ready-to-eat meat (Suya) and smoked fish. It is against this background that this study was designed to assess the presence and concentration of Polycyclic Aromatic Hydrocarbons.

\section{MATERIALS AND METHODS}

The study area is Awka urban, in Anambra State, Nigeria. Awka, the capital of Anambra state is situated on Latitude $6^{\circ} 12^{\prime} 25^{\prime \prime} \mathrm{N}$ and $7^{\circ} 04^{\prime}$ $04^{\prime \prime} \mathrm{E}$, with an elevation of $136 \mathrm{~m}$. Awka is the capital of Anambra State, Nigeria. Anambra State is one of the five states that make up the South East geopolitical zone. It has interstate boundaries with Delta State to the west, Imo and Rivers States to the south, Enugu State to the east and Kogi State to the north. It derives its name from the Anambra River (a tributary of the River Niger). The monsoon winds from the Atlantic create seven months of heavy tropical rains, which occur between the months of April and October and followed by five months of dryness between the months of November and March. The temperature of Awka is generally $27^{\circ}$ to $30^{\circ}$ Celsius, between June and December, but rises to between $32^{\circ}$ to $34^{\circ}$ Celsius, between January and April with the last few months of the dry season marked by intense heat.

\section{Study design}

The study design was a cross-sectional survey involving PAHs assessment in singed and unsinged hides and skin of cattle and goats and smoked and non-smoked fish.

\section{Sampling procedure and sampling sites}

Samples were collected from cattle hides and goats skin after slaughtering and singeing at "Kwata" slaughterhouse, Awka. About 20g portion of hides and skin were cut from each slaughtered animal. A systematic sampling technique of one out of every five animals slaughtered for processing was adopted for sample collection.

Fish tissues (muscle) were collected before and after the fish have been smoked for at least $6 \mathrm{~h}$. Purposive sampling technique was used to identify 6 major fish smoking spots that have a high level of patronage.

\section{Sample size and transportation}

Sample size was 60 samples, comprising 20 samples each from singed and unsigned hides from slaughtered cattle; 20 samples each from singed and unsigned skin from slaughtered goats and 20 samples each from smoked and non-smoked fish tissues. The 60 samples were arrived at, using the formula $\mathrm{n}=z^{2} \mathrm{p} / \mathrm{q}$ [13]; where $\mathrm{z}$ is constant 1.96 ; $\mathrm{p}=$ prevalence of previous study; $\mathrm{d}=$ Confidence interval, expressed as decimal (0.05); and $\mathrm{n}=$ sample size. The prevalence for determination of the sample size was based on the work of [14] which was $4 \%$. A minimum sample size of 59 was arrived at. The samples collected were put in different sterilized cellophane bags, which were labeled accordingly and tied tightly. They were then placed in a cooler containing ice blocks at $32{ }^{\circ} \mathrm{C}$ and transported to the laboratory (Springboard Laboratory, Awka, Anambra state) for analysis immediately. The remaining samples were kept at $7^{\circ} \mathrm{C}$.

\section{Laboratory analysis}

\section{Pretreatment}

Chemical drying of the samples was performed by grinding with Sodium sulphate $\left(\mathrm{NaSO}_{4}\right)$ which is a drying agent until the samples were reduced to fine consistency, so as to increase the surface interaction of solvent and matrix. This increased the homogeneity of the samples so as to increase the extractability of the analytes in the samples. Extraction of the samples was done using Soxhlet Extraction method first of all, rinse all the glass apparatus by petroleum ether and dry it in the oven at $102{ }^{\circ} \mathrm{C}$ and after removing it keep in the desiccator. 5 gram of grounded and dried sample was weighed and placed it in the thimble. The thimble was placed in the soxhlet extractor. A clean $150 \mathrm{ml}$ round bottom flask was filled with $90 \mathrm{ml}$ petroleum ether. The whole setting was placed on a heating mantle and the petroleum ether allowed to boil for several hours almost $6 \mathrm{~h}$. the sample was allowed to cool and almost all the solvent collected after distillation and sample weighed. Florisil cleanup method was used using traditional column chromatography. In the column cleanup protocol, the column is packed with the appropriate amount of adsorbent, topped with a water adsorbent, and then loaded with the sample extract. Elution of the analytes is effected with a suitable solvent(s) leaving the interfering compounds on the column. The eluate was further concentrated prior to gas chromatographic analysis.

\section{Data analysis}

Singed and unsigned goats skin, and smoked and non-smoked fish were compared using student's t-test. The concentrations in the three animals' species were subjected to one way ANOVA. Significance was accepted at $\mathrm{p} \leq 0.05$.

\section{RESULTS}

The results from this study showed that cattle hides and goat skin from Kwata slaughterhouse and fish in Awka area in Awka town accumulated varying levels of PAHs. Butchers used bamboo woods and animals fats for singeing hides and skin while fish sellers used charcoal fire for smoking fish. Out of 16 known PAHs components, 10 were detected in cattle hides, 12 in goatskin and 11 were detected in fish.

\section{Mean concentratons of PAHs}

Among the well-known human carcinogenic PAHs (a) benzo [a] pyrene; (b) benzo [a] fluoranthene; (c)benzo [a] anthracene; (d)indeno[1-2-3cd] pyrene(IARC, 1973 and EPA, 1985), only three components were detected in all the samples submitted.

\section{Cattle hides}

The mean concentration of carcinogenic PAHs in unsinged hides were $0.89 \pm 7.77$ for benzo[a]pyrene and $2.25 \pm 0.97$ for indeno[12-3cd]pyrene and none above maximum permissible levels (MPL) $30 \mu \mathrm{g} / \mathrm{kg}$ (EC, 2011). Two out of 8 components of noncarcinogenic PAHs detected were above the MPL, they are pyrene $42.42 \pm 22.76$ and benzo[b]fluoranthene $60.49 \pm 48.89$ as seen in table 1.

Upon singeing, the levels of these human carcinogenic PAHs increased but none above MPL, for benzo[a]pyrene from $0.89 \pm 7.77$ to $1.81 \pm 14.93$ and indeno[1-2-3cd]pyrene from $2.25 \pm 0.95$ to $3.55 \pm 2.89$. The two detected human non-carcinogenic PAHs components increased; pyrene from $42.42 \pm 22.76$ to $53.12 \pm 41.02$ and benzo[b]fluoranthene from $60.49 \pm 48.89$ to $89.84 \pm 42.27$.

Table 1: Mean concentrations $(\mu / \mathrm{kg})$ of PAHs in cattle hides at "Kwata" slaughterhouse

\begin{tabular}{llllll}
\hline PAHs & USH & SH & t-value & p-value & MPL \\
\hline Benzo[a]pyrene** & $0.89 \pm 7.77$ & $1.81 \pm 14.93$ & -1.49 & 0.15 & $30 \mu \mathrm{g} / \mathrm{kg}$ \\
Phenanthrene & $0.81 \pm 0.50$ & $2.28 \pm 0.72$ & -3.76 & $0.01^{*}$ & \\
Pyrene & $42.42 \pm 22.76$ & $53.12 \pm 4192$ & -0.56 & 0.59 & \\
Fluoranthene & $1.04 \pm 0.22$ & $2.31 \pm 0.82$ & -2.60 & 0.06 & \\
Chrysene & $7.58 \pm 1.00$ & $9.12 \pm 7.55$ & -0.27 & 0.08 & \\
Benzo[b]fluoranthene & $60.49 \pm 48.89$ & $89.84 \pm 42.27$ & -0.79 & 0.48 & \\
Acenaphthylene & $0.99 \pm 0.67$ & $3.91 \pm 2.60$ & -1.89 & 0.13 & \\
Acenaphthane & $0.15 \pm 0.18$ & $0.76 \pm 0.80$ & -1.28 & 0.25 & \\
Fluorene & $1.93 \pm 0.96$ & $2.68 \pm 2.00$ & -0.47 & 0.67 & \\
Indeno[1-2-3cd]pyrene** & $2.25 \pm 0.97$ & $3.55 \pm 2.29$ & -0.73 & 0.49 & $30 \mu \mathrm{g} / \mathrm{kg}$ \\
\hline
\end{tabular}

$\left({ }^{*}\right)=$ Human Carcinogenic PAHs: $\left({ }^{*}\right)=$ There is significant difference (significance accepted at $\left.\mathrm{p} \leq 0.05\right)$ : USH $=$ Unsinged Hides: SH $=$ Singed Hides: MPL = Maximum permissible level (EC, 2011). 


\section{Goatskin}

The mean concentration of human carcinogenic PAHs were; $0.52 \pm 10.77$ for benzo[a]pyrene; $6.58 \pm 5.93$ for benzo[k]fluoranthene and $3.48 \pm 0.00$ for indeno [1-2-3cd]pyrene. Out of the 9 non-human carcinogenic PAHs, only pyrene was detected above MPL$35.01 \pm 13.36$.
Upon singeing the levels of these human carcinogenic PAHs increased but none above MPL $(30 \mu \mathrm{g} / \mathrm{kg})$; benzo[a]pyrene from $0.52 \pm 10.77$ to $1.50 \pm 26.03$; benzo[k]fluoranthene from $8.68 \pm 5.93$ to $10.84 \pm 11.19$ and indeno[1-2-3cd]pyrene from $3.48 \pm 0.00$ to 8.79 \pm 11.77 . Flurothane and Fluorine increased above MPL19.49 \pm 26.49 to $90.06 \pm 172.26$ and $10.87 \pm 0.00$ to $30.27 \pm 0.00$ respectively as shown in table 2 .

Table 2: Mean concentration $(\mu \mathrm{g} / \mathrm{kg})$ of PAHs in goat skin at kwata slaughterhouse

\begin{tabular}{|c|c|c|c|c|c|}
\hline PAHs & USS & SS & t-value & p-value & MPL \\
\hline Benzo[a]pyrene** & $0.52 \pm 10.77$ & $1.50 \pm 26.03$ & -1.18 & 0.26 & $30 \mu \mathrm{g} / \mathrm{kg}$ \\
\hline Phenanthrene & $0.65 \pm 0.74$ & $1.90 \pm 2.13$ & -1.11 & 0.30 & \\
\hline Pyrene & $35.01 \pm 13.36$ & $123.77 \pm 59.02$ & -3.38 & $0.01^{*}$ & \\
\hline Fluoranthene & $19.49 \pm 26.49$ & $90.06 \pm 172.26$ & -0.90 & 0.39 & \\
\hline Chrysene & $3.04 \pm 1.00$ & $4.44 \pm 5.39$ & -0.43 & 0.68 & \\
\hline Benzo[b]fluoranthene & $8.68 \pm 13.86$ & $18.58 \pm 35.22$ & -0.45 & 0.67 & \\
\hline Acenaphthylene & $1.46 \pm 1.95$ & $3.07 \pm 3.40$ & -0.59 & 0.60 & \\
\hline Benzo[k]fluoranthene** & $6.58 \pm 5.93$ & $10.84 \pm 11.19$ & -0.76 & 0.47 & $30 \mu \mathrm{g} / \mathrm{kg}$ \\
\hline Naphthalene & $1.38 \pm 1.26$ & $5.23 \pm 4.85$ & -1.33 & 0.25 & \\
\hline Indeno[1-2-3cd]pyrene ${ }^{* *}$ & $3.48 \pm 00.00$ & $8.79 \pm 1.77$ & -0.37 & 0.78 & $30 \mu \mathrm{g} / \mathrm{kg}$ \\
\hline Acenaphthane & $0.40 \pm 0.00$ & $0.70 \pm 1.05$ & -0.56 & 0.62 & \\
\hline
\end{tabular}

$\left({ }^{* *}\right)=$ Human Carcinogenic PAHs: $\left(^{*}\right)=$ There is significant difference (significanceaccepted at $\mathrm{p} \leq 0.05$ ): USS $=$ Unsinged skin: SS $=$ Singed skin: MPL = Maximum permissible level (EC, 2011)

\section{Fish}

The mean concentrations of human carcinogenic PAHs in nonsmoked fish were, $0.65 \pm 9.67$ for benzo[a]pyrene; $2.11 \pm 2.16$ for benzo[k]fluoranthene and $54.76 \pm 60.35$ for indeno[1-2-3cd]pyrene. On smoking the levels of human carcinogenic PAHs increased; for benzo[a]pyrenefrom $0.65 \pm 9.67$ to $2.42 \pm 40.21$; benzo[k]fluoranthene from $2.11 \pm 2.16$ to $6.64 \pm 11.11$ and indeno [1-2-3cd]pyrene from $54.76 \pm 60.35$ to $599.36 \pm 1395.61$ which is far above MPL. Upon smoking, the mean concentration of some non-human carcinogenic PAHs increased; pyrene $28.12 \pm 16.45$ to $34.59 \pm 38.80$; fluoranthene from $23.60 \pm 21.38$ to $51.29 \pm 78.94$; Chrysene from $21.36 \pm 19.30$ to135.96 \pm 273.32 ; benzo[b]fluoranthene $15.75 \pm 25.12$ $164.00 \pm 380.05$ and fluorene from $11.88 \pm 7.13$ to $32.91 \pm 36.48$.

Table 3: Mean concentrations $(\mu \mathrm{g} / \mathrm{kg})$ of PAHs in fish in awka town

\begin{tabular}{|c|c|c|c|c|c|}
\hline PAHs & NSF & SF & t-value & p-value & MPL \\
\hline Benzo[a]pyrene ${ }^{* *}$ & $0.65 \pm 9.67$ & $2.42 \pm 40.21$ & 0.55 & 0.59 & $30 \mu \mathrm{g} / \mathrm{kg}$ \\
\hline Phenanthrene & $0.86 \pm 1.09$ & $3.12 \pm 2.17$ & -1.63 & 0.16 & \\
\hline Pyrene & $28.12 \pm 16.45$ & $34.59 \pm 38.80$ & 0.52 & 0.61 & \\
\hline Fluoranthene & $23.60 \pm 21.38$ & $51.29 \pm 78.94$ & -0.59 & 0.59 & \\
\hline Chrysene & $21.36 \pm 19.30$ & $135.96 \pm 273.32$ & 0.63 & 0.54 & \\
\hline Benzo[a]fluoranthene & $15.75 \pm 25.12$ & $164.00 \pm 380.05$ & 0.91 & 0.38 & \\
\hline Acenaphthylene & $0.11 \pm 0.13$ & $1.45 \pm 0.84$ & -0.06 & 0.95 & \\
\hline Benzo[k]fluoranthene** & $2.11 \pm 2.10$ & $6.64 \pm 11.11$ & -0.91 & 0.38 & $30 \mu \mathrm{g} / \mathrm{kg}$ \\
\hline Naphthalene & $1.34 \pm 0.94$ & $1.88 \pm 2.43$ & -0.91 & 0.41 & \\
\hline Fluorene & $11.88 \pm 7.13$ & $32.91 \pm 36.48$ & 0.64 & 0.59 & \\
\hline Indeno[1-2-3cd]pyrene $e^{* *}$ & $54.76 \pm 60.35$ & $599.36 \pm 1395.61$ & -0.76 & 0.47 & $30 \mu \mathrm{g} / \mathrm{kg}$ \\
\hline
\end{tabular}

$\left.{ }^{* *}\right)=$ Human Carcinogenic PAHs: NSF = Non-smoked fish: SF = Smoked fish: MPL = Maximum permissible level (EC, 2011): There is no significant difference in mean concentration of NSF/SF (significance accepted at $\mathrm{p} \leq 0.05$ )

\section{DISCUSSION}

The finding in this present study showed that PAHs were present in the sample analyzed in variable quantity which agrees with recent work conducted by [15] who observed the appreciable amount of PAHs both raw and smoked food items. The finding in this present study however contrast with the report of [1] at Ammossma, Niger Delta, Nigeria who detected 15 PAHs in reasonable quantity in the roasted food items and 3 were found in 'Suya'beef, but none was detected in the raw food items and roasted plantain. The high concentration of PAHs recorded in this study in the unsinged hides and skin and non-smoked fish may be attributed to the presence of PAHs in the local environment which the animals could easily have come in contact with through scavenging in open waste or refuse dumps, free range grazing drinking water from polluted streams and drains, polluted lakes and rivers and exposure to atmospheric depositions especially from automobile fumes, agricultural chemicals and open burning of solid wastes. The industrial activities within Awka area of Anambra State, which constitute the majority of the cattle and goat feed during free ranching as practiced in Nigeria [16]. Apart from the slight commercial activities in Awka, the available concentration of the PAHs in raw food could be hypothetically linked to proximity of Awka close to the heavily populated and industrially active city of Onitsha. Also, weather changes and wind dispersion could transport the substances and become deposited at non-impact areas [17]. Most PAHs do not dissolve easily in water. They stick to solid particles and settle to the bottom of lakes or rivers thus may account for the presence and high concentrations of PAHs in the non-smoked fish in this work. [14], in their work reported that there were a high concentration of PAHs in dump sites in Awka. This shows that refuse dumps sites are the possible major source of PAHs in Awka. This may suggest that food animals awaiting slaughter slab in Kwata slaughter may have been scavenging or grazing at these dump sites. The high concentration of some of these PAHs in smoked fish samples than in singed hides and skin could be due to the longer smoking duration of fish (6hours) than that of hides and skin (30 min to 1hour) as observed by [18]; higher fat content of fish as observed by [19] and pyrolysis resulting 
from melted fat from fish dropping onto the heat source [20]. Among the well-known human carcinogenic PAHs: benzo[a]anthracene; benzo[a]pyrene; benzo[k]fluoranthene and indeno[1-2-3cd]pyrene (IARC, 1973 and EPA, 1985), only three components were detected in all the samples analysed: benzo[a] pyrene $(\mathrm{B}[\mathrm{a}] \mathrm{P})$; benzo[k] fluoranthene $(\mathrm{B}[\mathrm{K}] \mathrm{F})$; and indeno[1-2-3cd]pyrene (IP). The mean concentration of human carcinogenic PAHs in all the three species of animals was below the EC, maximum permissible level except Indeno [1-2-3cd]pyrene (IP) in fish (non-smoked and smoked fish) which was far above EC, MPL. This might pose health problems to those who might have consumed fish from the source of this sample. This shows that there may be high accumulations of PAHs from the source of water (lake, or river) from which the sampled fishes were collected.

In this work IP mean concentration in non-smoked and smoked fish were above EC, MPL (54.76 and $599.36 \mu \mathrm{g} / \mathrm{kg}$ respectively) and these were in contrast with the reports of [4] which showed lower mean concentration of IP $(6.4 \mu \mathrm{g} / \mathrm{kg}$ in smoked fish and not available in non-smoked fish). Findings in this present study however, agreed with the rest of human carcinogenic PAHs detected (i.e. B[a]P and $\mathrm{B}[\mathrm{k}] \mathrm{F}$ ), which were not above EC, MPL $30 \mu \mathrm{g} / \mathrm{kg}$, [21]. The range of values of concentration of $\mathrm{B}[\mathrm{a}] \mathrm{P}$ in smoked fish recorded in this present study agreed with the range reported by Akpan et al.,(1994); was different from that of [4] and [22] which had 2.4$31.2 \mu \mathrm{g} / \mathrm{kg}$ and $11.1-66.9 \mu \mathrm{g} / \mathrm{kg}$ respectively.

\section{CONCLUSION}

In this study, the elevated PAHs concentration in the samples processed may be attributed to the incomplete combustion of the materials. The study concluded that human carcinogenic PAHs contaminant in the fish exceeds the acceptable limit, and therefore of public health risk when such fish is consumed.

\section{AUTHORS CONTRIBUTIONS}

All the author have contributed equally

\section{CONFLICT OF INTERESTS}

Declare none

\section{REFERENCES}

1. Afolabi OA, Adesulu EA, Oke OL. Polynuclear aromatic hydrocarbons in some Nigeria preserved freshwater fish species. J Agric Food Chem 1983;31:1083-90.

2. Agbozu IE. Polycyclic aromatic hydrocarbons composition and source in food snacks in university com Nigeria. Res J Chem Environ Sci 2014;2:26-31.

3. Akpambang VOE, Amoo IA, Conte LS, Moret S, Lajide L, Purcao G. Determination of polycyclic aromatic hydrocarbons in commonly consumed Nigeria smoked/grilled fish and meat. Food Additive Contaminants: Part A 2009;26:1090-103.

4. Amos Tauttau BMW, Abasi CY, Amirize GC, Inengite AK. Evaluation of polycyclic aromatic hydrocarbons and some heavy metals in roasted food snacks in Amassoma, Niger Delta, Nigeria. Afr J Environ Sci Technol 2013;7:961-6.

5. European Commission (EC): Commission regulation (EU) No 835/2011 of August. Amend in Maximum level for Polycyclic Aromatic Hydrocarbons in foodstuffs. (Text with EEA relevance) Official Journal of European Union; 2001.

6. Heba HM. Distribution of trace elements in the white muscle and some key organs of fish species from AL-hodeida red sea coastof yemen. Proc ICBS 2004;3:435-54.

7. Ihekoronye AI, Ngoddy PO. Integrated food science and technology for the tropic. Macmillan Publishers Limited. Van
derrOost R. Bayer J, Vermeulen NP. Fish bioaccumulation and biomarkers in environmental risk assessment: a review. Environ Toxicol Pharmacol 1985;13:57-149.

8. Jeffery AM, Grunberge RD, Katz L, Kinoshita T, Santella RM, Weinstein IB. The chemistry of polycyclic aromatic hydrocarbonsDNA adduts. In. B Pullman, PO Tso, HV Gelboin. Eds. Carcinogenesis: fundamental mechanisms and environmental effects: Boston. D. Rendell Publications; 1980. p. 565-79.

9. Knize MG, Felton JS, Paris P, Salmon CP. Food heating and the formation of the heterocyclic aromatic amine and PAHs mutagens/Carcinogens. In: LS Jackson, MG Knize, JNM Organ. Ed. Impact of processing on food safety. New York: Khiwer Academic; 1999.

10. Larson BK, Busk LA, Eriksson AT, Stahlberg GP. Polycyclic aromatic hydrocarbons in grilled food. J Agric Food Chem 1983;31:867-73.

11. Liang Y, Tse MF, Woung MH, Young L. Distribution pattern of polycyclic aromatic hydrocarbons (PAHs) in sediments and fish at mai PO marshes nature reserve, hong kong. Water Res 2007;41:1303-11.

12. Linda MN, Caboo PD, Darko A, Gorleku MA, Mordecai A, Quasie WJ, et al. Characterization of polycyclic aromatic hydrocarbons (PAHs), present in smoked fish from ghana. Advance J Food Sci Technol 2011;3:332-8.

13. Miller EC. Some current perspective on chemical carcinogenesis inhumans and experimental animals. Cancer Res 1978;38:1479-96.

14. Akpan V, Dolara P, Lodovici M. Polycyclic aromatic hydrocarbons in fresh and smoked fish samples from the three Nigeria cities. Bull Environ Contam Toxicol 1994;53:246-53.

15. Nduka JK, Anyakora E, Ezenwa TE, Ngozi Olehi LC, Obi E, Obumeselu FO. Polycyclic aromatic hydrocarbon (PAHs) and inorganic chemical contaminants at refuse dumps site in awka, South Eastern Nigeria. A publication health implication. J Sci Res Reports 2013;2:173-189.

16. Ogbuagu DH, Ayoade AA. Presence and levels of common polynuclear aromatic hydrocarbons (PAHs) in staple foods of Ngeria. Food Public Health 2012;2:50-4.

17. Scientific Committee on Food of EC (SFC). Opinion of the scientific committee on food in the risk to human health of PAHs in food. Brussels; 2002.

18. Sim RC, Overcash R. Fate of polynuclear aromatic compound (PNA) in soil-plant systems. Residue Revission 1983;88:1-68.

19. Thrusfield M. Veterinary Epidemiology. $3^{\text {rdedition; } 2007 .}$

20. Ujowundu CO, Alisi CS, Igwe CU, Ihekweazu KL, Ujowundu FN. Procarcinogens: PAHs and heavy metals content in some locally processed foods in South Eastern Nigeria. Br J Appl Sci Technol 2014;4:249-60.

21. Van Derr Oost R, Bayer J, Vermeulen NP. Fish bioaccumulation and biomarkers in environmental risk assessment: a review. Environ Toxicol Pharmacol 2003;13:57-149.

22. Visceano P, Amorena M, Lanieri A, Perugini M. Polycyclic aromatic hydrocarbons in fresh and cold-smoked atlantic salmon fillets. J Food Protection 2006;69:1113-38.

23. Watson AY, Batre RR, Kennedy D. editors. Air pollution, the automobile, and public health, Washington (DC): National Academies Press (US): atmospheric transport and dispersion of air pollutants association with vehicular emission; 1988. Available from: http://www.ncbi.nlm.gov/books/NBK218142/ [Last accessed on 10 Oct 2018].

24. World Health Organization (WHO). Polycyclic aromatic hydrocarbons WHO food additives series 55: safety evaluation of certain contaminants in food International programme of chemical safety (IPCS) WHO Geneva; 2006. p. 563-743. 